\section{PENGARUH PELAKSANAAN KEBIJAKAN SUNSET POLICY, TAX AMNESTY, DAN SANKSI PAJAK TERHADAP KEPATUHAN WAJIB PAJAK ORANG PRIBADI}

\author{
Nur Alfiyah, Sri Wahjuni Latifah \\ Program Studi Akuntansi Fakultas Ekonomi dan Bisnis \\ Universitas Muhammadiyah Malang \\ Jl. Raya Tlogomas No.246 Malang \\ Email: Alfiyahnur24@gmail.com
}

Abstract

This research aims to provide empirical evidence of the influence of implementation of Sunset Policy, Tax Amnesty, and Tax sanctions on individual' Taxpayer who run the business activities and work free in KPP Pratama Dompu. The number of respondents in this research are 58 individual taxpayers who run the business activities and work free which was listed in KPP Pratama Dompu. The type of data used in this research is primer data obtained from the distributions of questionnaires containing the answers from respondents. The analysis method of this research is logistic regression analysis. The result indicates that sunset policy, tax amnesty, and tax sanctions have significant effect on taxpayer compliance of individual in Dompu District.

Keywords: Sunset Policy, Tax Amnesty, Tax Sanctions, and Taxpayer Compliance.

\title{
PENDAHULUAN
}

Pajak merupakan tulang punggung penerimaan negara dan digunakan untuk membiayai sektok-sektor negara seperti sektor pendidikan, kesehatan, sarana umum, dan lain-lain, (Ngadiman \& Huslin,2015). Untuk merealisasikan tujuan tersebut diperlukan upaya dalam hal peningkatan penerimaan pajak dengan menggali sumber dana yang berasal dari dalam negeri, yaitu melalui peningkatan kepatuhan wajib pajak. Kepatuhan wajib pajak merupakan faktor penting dalam merealisasikan target penerimaan pajak. Semakin tinggi kepatuhan wajib pajak, maka penerimaan pajak akan semakin meningkat. Akan tetapi dalam kenyataannya, keinginan masyarakat untuk membayarkan pajak masih tergolong rendah. Menurut wakil mentri keuangan berdasarkan data Dirjen Pajak, bahwa setoran pajak dari kelompok wajib pajak orang pribadi sejauh ini terlalu rendah. Terutama wajib pajak dari kalangan non karyawan atau memiliki pekerjaan sendiri termasuk usaha profesi. Hal ini menunjukkan bahwa wajib pajak orang pribadi seperti pengusaha dan profesi belum memenuhi kewajiban pajaknya dengan baik, (Ngadiman dan Huslin,2015).

Penurunan penerimaan pajak yang terjadi membuat Direktorat Jenderal Pajak harus berupaya mengoptimalkan pelayanan sehingga diharapkan dapat meningkatkan kesadaran dan keinginan masyarakat untuk tertib sebagai Wajib Pajak, salah satunya dengan melakukan reformasi kebijakan perpajakan yang diimplementasikan dalam bentuk regulasi pemerintah dengan memberlakukan kebijakan sunset policy, tax amnesty dan sanksi pajak, (Gunadi dalam Rahman, 2010:210).

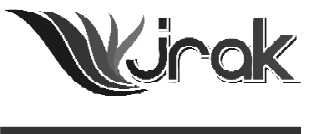

Jurnal Reviu Akuntansi dan Keuangan ISSN: 2088-0685 Vol. 7 No. 2, Oktober 2017 Pp 1081-1090 


\section{Pengaruh Pelaksanaan Kebijakan...}

1082
Presiden Joko Widodo (Jokowi) pada 1 Juli 2016 mengesahkan UndangUndang tentang Pengampunan Pajak atau Tax Amnesty. Dalam UU itu ditegaskan, bahwa Pengampunan Pajak adalah penghapusan pajak yang seharusnya terutang, tidak dikenai sanksi administrasi perpajakan dan sanksi pidana di bidang perpajakan, dengan cara mengungkap harta dan membayar uang tebusan sebagaimana diatur dalam Undang-Undang ini.

Namun sebelum itu, Direktorat Jenderal Pajak pada tahun 2008 telah mengeluarkan kebijakan pajak bagi Wajib Pajak yang secara sukarela melakukan pembetulan atas pelaporan pajak tahun-tahun yang lalu dan juga memberikan kelonggaran bagi masyarakat untuk memperoleh Nomor Pokok Wajib Pajak (NPWP), yang dikenal dengan Sunset Policy. Menurut Rahayu (2009: 344) Sunset Policy merupakan program penghapusan sanksi administrasi Pajak Penghasilan sebagai bentuk pemberian fasilitas perpajakan yang diatur berdasarkan Pasal 37A UU Nomor 28 Tahun 2007 tentang Ketentuan Umum dan Tata Cara Perpajakan.

Sebagai upaya untuk melakukan terobosan khususnya dalam penggalian potensi perpajakan guna mengontrol perilaku wajib pajak agar wajib pajak mematuhi peraturan perpajakan dan sebelum adanya beberapa kebijakan perpajakan tersebut, Dirjen Pajak telah memberlakukan sanksi perpajakan yaitu suatu tindakan berupa hukuman yang diberikan kepada orang yang melanggar peraturan berupa sanksi administrasi dan sanksi pidana tanpa adanya penghapusan sanksi seperti yang diberlakukan pada tax amnesty dan sunset policy, (Ngadiman dan Huslin, 2015).

Terdapat beberapa penelitian yang dilakukan oleh peneliti terdahulu yaitu menurut pandangan Widodo (2008) bahwa kebijakan sunset policy dapat meningkatkan pendapatan pajak negara dengan meningkatnya kepatuhan wajib pajak. Sunset policy dapat mendorong wajib pajak untuk memenuhi aspek-aspek formal kewajiban perpajakannya.

Selain itu penelitian yang dilakukan oleh Gunawan dan Sukartha (2016) mengenai faktor yang mempengaruhi penerimaan pajak tahun 2015 di KPP pratama Badung Utara yang diduga salah satunya dipengaruhi oleh tax amnesty menemukan hasil bahwa tax amnesty berpengaruh positif terhadap penerimaan pajak di KPP Badung Utara. Kebijakan tax amnesty ini direspon secara positif oleh wajib pajak, yaitu dengan semakin meningkatnya kemauan membayar pajak.

Penelitian sejenis lainnya dilakukan oleh Mutia (2014), mengenai pengaruh sanksi perpajakan terhadap kepatuhan wajib pajak di KPP Pratama Padang. Hasil penelitian menunjukkan bahwa terdapat hubungan yang signifikan dan positif antara sanksi perpajakan dengan kepatuhan wajib pajak. Hal ini berarti semakin tinggi sanksi perpajakan, maka kepatuhan wajib pajak akan tercapai.

Berdasarkan masalah yang telah dipaparkan mengenai banyaknya wajib pajak orang pribadi non karyawan atau usaha profesi yang cenderung untuk meloloskan diri dari kewajibannya untuk menyetorkan pajak serta banyaknya orang pribadi maupun badan usaha yang melakukan tindakan tax avoidance (penghindaran pajak) yang sering kali menjurus pada praktik tax evasion (penggelapan pajak), seperti yang dilansir dari Panama Papers yang sejak tahun 2015 lalu ramai diperbincangkan, memberikan bocoran tentang maraknya kegiatan ekonomi bawah tanah yang dilakukan WP pribadi maupun badan usaha baik di dalam negri maupun luar negri yang melakukan penghindaran pajak secara ilegal.

Dompu merupakan salah satu kota kecil di Provinsi Nusa Tenggara Barat yang terbilang belum maju sehingga angka kepatuhan wajib pajaknya masih sangat rendah terutama pada wajib pajak orang pribadi yang melakukan kegiatan usaha dan perkerjaan bebas, serta sangat minimnya dilakukan penelitian di lokasi tersebut dan ditinjau dari penelitian-penelitian sebelumnya bahwa banyak peneliti yang lebih fokus meneliti fenomena yang terjadi di kota-kota besar saja. Penelitian ini bertujuan untuk membuktikan secara empiris pengaruh pelaksanaan kebijakan Sunset Policy, Tax Amnesty, dan Sanksi Pajak terhadap Kepatuhan Wajib Pajak Orang Pribadi yang melakukan kegiatan usaha dan pekerjaan bebas yang terdaftar di KPP Pratama di Kabupaten Dompu. 


\section{Pengaruh Sunset Policy terhadap Kepatuhan Wajib Pajak}

Berdasarkan teori atribusi, sunset policy merupakan penyebab eksternal yang mempengaruhi persepsi wajib pajak untuk berperilaku patuh dalam melaksanakan kewajiban perpajakan. Berdasarkan teori pembelajaran sosial, wajib pajak dapat belajar melalui pengamatan dan pengalaman langsung mengenai dampak diberlakukannya program sunset policy, untuk mengetahui apa fungsi serta keuntungan bila mengikuti program tersebut. Keberadaan sunset policy merupakan kesempatan terbatas yang diberikan Pemerintah kepada organisasi atau individu untuk meningkatkan ketaatan terhadap peraturan pajak.

Penelitian yang dilakukan oleh Syaputri (2009) mengenai penerapan ketentuan pasal 37A undang-undang nomor 28 tahun 2007 tentang Sunset Policy dalam rangka peningkatan wajib pajak orang pribadi, menyimpulkan bahwa program Sunset Policy ini telah membuahkan hasil yang baik dalam meningkatkan jumlah Wajib Pajak khususnya Orang Pribadi dan Penerimaan Pajak di KPP Pratama Jakarta Pademangan. Hal ini dapat dilihat dari jumlah peningkatan Wajib Pajak Orang Pribadi yang cukup signifikan dibandingkan pada masa sebelum diberlakukannya Sunset Policy. Berdasarkan hal tersebut, maka hipotesis yang diajukan pada penelitian ini adalah:

$\mathrm{H}_{1}$ : Sunset Policy berpengaruh positif terhadap kepatuhan wajib pajak.

\section{Pengaruh Tax Amnesty terhadap Kepatuhan Wajib Pajak}

Berdasarkan teori atribusi, tax amnesty merupakan penyebab eksternal yang mempengaruhi persepsi wajib pajak untuk berperilaku patuh dalam melaksanakan kewajiban perpajakan. Berdasarkan teori pembelajaran sosial, wajib pajak dapat belajar melalui pengamatan dan pengalaman langsung mengenai dampak diberlakukannya program tax amnesty, untuk mengetahui apa fungsi serta keuntungan bila mengikuti program tersebut. Keberadaan tax amnesty merupakan kesempatan terbatas yang diberikan Pemerintah kepada organisasi atau individu untuk meningkatkan ketaatan terhadap peraturan pajak.

Alm (2009) mengatakan bahwa tax amnesty berpengaruh positif pada penerimaan pajak. Keberadaan tax amnesty meningkatkan kepatuhan sukarela di masa yang akan datang. Darusalam (2011) mengatakan bahwa tax amnesty diperlukan untuk menarik kelompok masyarakat yang belum masuk ke dalam sistem administrasi perpajakan untuk masuk dan menjadi bagian dari sistem administrasi perpajakan sehingga dapat berperan serta dalam pembagunan negara. Berdasarkan hal tersebut, maka hipotesis yang diajukan pada penelitian ini adalah: $\mathrm{H}_{2}$ : Tax Amnesty berpengaruh positif pada kepatuhan wajib pajak.

\section{Pengaruh Sanksi Pajak terhadap Kepatuhan Wajib Pajak}

Berdasarkan teori atribusi, sanksi perpajakan merupakan penyebab eksternal yang mempengaruhi persepsi wajib pajak dalam penilaian mengenai perilaku kepatuhan wajib pajak untuk melaksanakan kewajiban perpajakan. Berdasarkan teori pembelajaran sosial, wajib pajak dapat belajar melalui pengamatan dan pengalaman langsungnya melalui pemberian sanksi yang dikenakan aparat pajak kepada wajib pajak yang melanggar norma perpajakan. Sanksi pajak dibuat adalah untuk mendukung agar wajib pajak mematuhi peraturan perpajakan. Kepatuhan wajib pajak akan ditentukan berdasarkan persepsi wajib pajak tentang seberapa kuat sanksi pajak mampu mendukung perilaku wajib pajak untuk taat pajak (Arum 2012: 28).

Menurut Zain (2007:35) menyatakan bahwa sesungguhnya tidak diperlukan suatu tindakan apabila dengan rasa takut dan ancaman hukuman (sanksi dan pidana) saja wajib pajak sudah akan mematuhi kewajiban perpajakannya perasaan 
Pengaruh

Pelaksanaan

Kebijakan...

1084

Gambar 1

Gambar model penelitian empiris takut tersebut merupakan alat pencegah ampuh untuk mengurangi peyelundupan pajak atau kelalaian pajak.jika hal ini sudah berkembang dikalangan para wajib pajak maka akan berdampak pada kepatuhan dan kesadaran untuk memenuhi kewajiban perpajakannya. Berdasarkan hal tersebut, maka hipotesis yang diajukan pada penelitian ini adalah:

$\mathrm{H}_{3}$ : Sanksi Pepajakan berpengaruh positif terhadap kepatuhan wajib pajak.

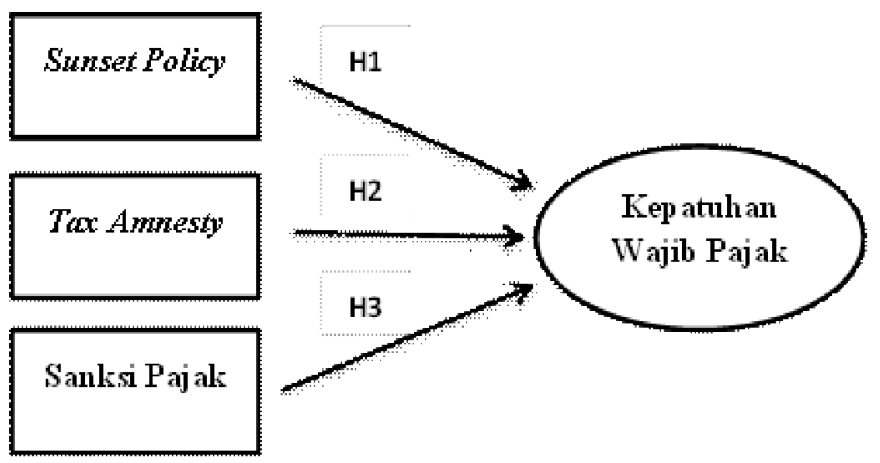

\section{METODE}

Penelitian ini merupakan penelitian asosiatif yang menggunakan metode penyebaran kuisioner untuk mendapatkan data penelitiannya. Jumlah responden dalam penelitian ini adalah sebanyak 58 wajib pajak orang pribadi yang melakukan kegiatan usaha dan pekerjaan bebas yang terdaftar di KPP Pratama Kabupaten Dompu dengan menggunakan teknik Random Sampling. Jenis data yang digunakan adalah data primer yang diperoleh langsung dari penyebaran kuesioner yang berisi jawaban dari responden. Metode analisis pada penelitian ini adalah analisis regresi logistik dan didukung oleh statistik deskriptif dan uji instrumen.

Instrumen yang digunakan dalam penelitian ini adalah instrumen kuesioner untuk Kepatuhan Wajib Pajak, Sunset Policy, Tax Amnesty, dan Sanksi Pajak. Penelitian ini menggunakan instrumen kuisioner yang diadaptasi dari penelitian yang dilakukan oleh Wahyudi (2017) serta Ngadiman dan Huslin (2015) yang telah teruji secara validitas dan reliabilitas dan setiap konstruk pertanyaan diberi skor menggunakan skala likert 1-5 untuk mengukur jawaban dari responden berupa pernyataan: sangat tidak setuju, tidak setuju, tidak ada pendapat, setuju, dan sangat setuju. Berikut bebarapa indikator pengukurannya:

\begin{tabular}{|c|c|c|}
\hline Dimensi & Indikator & Skala \\
\hline $\begin{array}{l}\text { 1. Kepatuhan } \\
\text { Administratif }\end{array}$ & $\begin{array}{l}\text { 1. Ketentuan batas waktu penyampaian } \\
\text { Surat Pemberitahuan (SPT). } \\
\text { 2. Tepat waktu dalam menyampaikan Surat } \\
\text { Pemberitahuan (SPT). } \\
\text { 3. Tidak mempunyai tunggakan Pajak untuk } \\
\text { semua jenis pajak. } \\
\text { 4. Tidak pernah dijatuhi hukuman karena } \\
\text { melakukan tindak pidana di bidang } \\
\text { perpajakan. }\end{array}$ & Likert \\
\hline $\begin{array}{l}\text { 2. Kepatuhan } \\
\text { Teknis }\end{array}$ & $\begin{array}{l}\text { 1. Wajib Pajak mengisi dengan jujur, } \\
\text { lengkap dan benar SPT sesuai ketentuan } \\
\text { dan menyampaikannya ke KPP Pratama } \\
\text { Kabupaten Dompu. }\end{array}$ & Likert \\
\hline
\end{tabular}




\begin{tabular}{crc}
\hline Dimensi & \multicolumn{1}{c}{ Indikator } & Skala \\
\hline 1. & Sunset Policy memberikan fasilitas \\
& perpajakan dalam bentuk penghapusan & \\
& sanksi administrasi peprajakan. & \\
& 2. $\begin{array}{l}\text { Sunset Policy memberikan kesempatan } \\
\text { kepada masyarakat untuk memperoleh }\end{array}$ & \\
& NPWP. & Likert \\
1. Kemanfaatan & Sunset Policy memberikan kesempatan & \\
& kepada Wajib Pajak untuk melakukan & \\
& pembetulan SPT. & \\
& Wajib Pajak yang mengikuti program & \\
& Sunset Policy dibebaskan dari & \\
& pemeriksaan. & \\
\hline
\end{tabular}

perpajakan dalam bentuk penghapusan

kepada masyarakat untuk memperoleh NPWP.

kepada Wajib Pajak untuk melakukan

Wajib Pajak yang mengikuti program

pemeriksaan

Tabel 2.

Sunset Policy

\begin{tabular}{lll}
\hline \multicolumn{1}{c}{ Dimensi } & \multicolumn{1}{c}{ Indikator } & Skala \\
\hline & 1) Meningkatkan kepatuhanWajib Pajak. & \\
& 2) Mendorong kejujuran Wajib Pajak dalam & \\
1. Tujuan & hal pelaporan harta kekayaan. & Likert \\
& 3) Mendorong repatriasi modal atau aset. & \\
& 4) Sebagai alat transisi menuju sistem & \\
& 5erpajakan yang baru. & \\
& Dapat meningkatkan pendapatan Negara & \\
& 1) Walam waktu jangka pendek. & Likert \\
& Amnesty tidak diperiksa. & \\
2. Kemanfaatan & Wajib Pajak yang mengikuti program Tax & \\
& Amnesty tidak diberikan sanksi & \\
& perpajakan. & \\
& 3) Wajib Pajak yang mengikuti program & Tax Amnesty tidak diberikan denda. \\
\hline
\end{tabular}

Tabel 3.

Tax Amnesty

\begin{tabular}{ccc}
\hline Dimensi & \multicolumn{1}{c}{ Indikator } & Skala \\
\hline & $\begin{array}{l}\text { 1. Sanksi pajak diperlukan agar tercipta } \\
\text { kedisiplinan Wajib Pajak. }\end{array}$ & \\
2. Kemanfaatan & $\begin{array}{l}\text { Pengenaan sanksi pajak dapat } \\
\text { menumbuhkan efek jera kepada Wajib }\end{array}$ & Likert \\
& $\begin{array}{l}\text { Pajak yang tidak patuh. } \\
\text { 3. }\end{array}$ & \\
& Pengenaan sanksi pajak dapat & \\
& 1. Pemberian sanksi pajak harus sesuai & \\
& dengan ketentuan yang berlaku. & Likert \\
2. Teknis & Wajib Pajak yang tidak patuh akan & \\
& dikenakan sanksi perpajakan. &
\end{tabular}

Tabel 4.

Sanksi Pajak

Analisis data dilakukan dengan tahapan:

Uji Instrumen. Penelitian ini menggunakan instrumen kuisioner yang diadaptasi dari penelitian yang dilakukan oleh Wahyudi (2017) serta Ngadiman dan Huslin (2015) yang telah teruji secara validitas dan reliabilitas, sehingga dapat disimpulkan bahwa seluruh konstruk pertanyaan pada kuisioner adalah valid dan reliabel dan pada penelitian ini tidak dilakukan pengujian ulang. Kemudian dilanjutkan dengan Statistik Deskriptif. Statistik deskriptif menggambarkan karakteristik umum dari sampel yang digunakan dalam penelitian ini dengan lebih rinci. 


\section{Pengaruh Pelaksanaan Kebijakan...}

1086
Analisis Regresi Logistik. Regresi Logistik adalah regresi yang digunakan untuk menguji sejauhmana probabilitas terjadinya variabel dependen dapat diprediksi dengan variabel dengan variabel independen. Pada analisis regresi logistik tidak memerlukan lagi uji normalitas dan uji asumsi klasik pada variabel bebasnya. Hal ini karena regresi logistik adalah regresi dimana variabel terikatnya adalah variabel dummy. Tahap-tahap pengujian regresi logistik adalah sebagai berikut: Menguji Kelayakan Model Regresi (Hosmer and Lemeshow's Goodness of Fit Test Goodness), Menilai Keseluruhan Model (Overall Model Fit Test), Koefisien Determinasi (R2), Pengujian Simultan (Omnibus Test of Model Coefficient), Uji Multikolinearitas, Pengujian Hipotesis.

\section{HASIL DAN PEMBAHASAN}

Populasi dalam penelitian ini adalah seluruh wajib pajak orang pribadi yang ada di lingkungan KPP Pratama Kabupaten Dompu. Jangka waktu penyebaran kuesioner pada periode 2 tax amnesty berakhir, yaitu mulai bulan Mei 2017 Juni 2017. Berdasarkan penentuan sampel yang dilakukan, terdapat 81 wajib pajak yang ditemui peneliti dan bersedia menjadi responden dalam penelitian ini. Akan tetapi hanya 58 kuesioner yang layak untuk diolah lebih lanjut dalam penelitian dan sesuai dengan kriteria yaitu responden mengikuti program sunset policy dan tax amnesty, mayoritas responden yang ditemui secara acak merupakan pekerja bebas atau pelaku usaha.

\section{Statistik Deskriptif}

Tabel 5 .

\begin{tabular}{lccccc}
\hline & N & Minimum & Maximum & Mean & Std. Deviation \\
\hline SunsetPolicy & 58 & 15,00 & 34,00 & 27,3276 & 4,35039 \\
TaxAmnesty & 58 & 21,00 & 45,00 & 35,1034 & 5,46340 \\
SanksiPajak & 58 & 12,00 & 30,00 & 24,0172 & 4,52863 \\
KepatuhanWP & 58 & 17,00 & 34,00 & 27,9310 & 5,84256 \\
Valid N (listwise) & 58 & & & & \\
\hline
\end{tabular}

Berdasarkan tabel 5 dapat diketahui bahwa jumlah sampel data valid yang akan diteliti adalah 58 responden. Sunset policy, tax amnesty, dan sanksi pajak memiliki nilai rata-rata yang mendekati nilai rata-rata kepatuhan WP yang artinya bahwa sebagian besar responden cenderung menjawab setuju untuk pertanyaan yang diajukan mengenai partispasi langsung pada program sunset policy dan tax amnesty serta manfaat dan keuntungan yang diperoleh setelah mengikuti program tersebut, dan peran sanksi pajak dalam meningkatkan kepatuhan wajib pajak, sehingga dapat disimpulkan bahwa WP yang mengikuti program sunset policy, tax amnesty, maupun WP yang memahami tentang sanksi pajak cenderung patuh terhadap kewajiban perpajakannya.

\section{Analisis Regresi Logistik}

Kelayakan model regresi dinilai dengan menggunakan Hosmer and Lemeshow's Goodness of Fit Test. Berdasarkan hasil pengujian tersebut menunjukkan bahwa nilai yang dihasilkan jauh diatas nilai alpha $(\alpha=0,05)$. Hal ini berarti model regresi layak untuk digunakan dalam analisis selanjutnya, karena tidak ada perbedaan yang nyata antara klasifikasi yang diprediksi dengan klasifikasi yang diamati (model mampu memprediksi nilai observasinya).

Penilaian keseluruhan model dilakukan dengan membandingkan nilai antara -2 Log Likelihood pada awal (Block Number $=0$ ), dimana hanya memasukkan konstanta, dengan nilai - 2 Log Likelihood pada akhir (Block Number $=1$ ), dimana model memasukkan konstanta dan variabel independen. Berdasarkan hasil 
pengujian tersebut nilai -2 Log Likelihood awal mengalami penurunan setelah dimasukkan ketiga variabel independen pada nilai -2 Log Likelihood akhir. Penurunan nilai -2 Log Likelihood ini menunjukkan model regresi yang baik atau dengan kata lain model fit dengan data.

Koefisien determinasi digunakan untuk mengetahui seberapa besar variabilitas variabel dependen dengan melihat nilai Nagelkerke $R$ Square. Berdasarkan hasil pengujian yang dilakukan variabilitas kepatuhan WP yang dapat dijelaskan oleh sunset policy, tax amnesty dan sanksi pajak adalah sebesar 53,5 persen, sisanya 46,5 persen dijelaskan oleh variabel-variabel lainnya di luar model penelitian.

Pengujian simultan dilakukan untuk menguji apakah Sunset Policy, Tax Amnesty, dan Sanksi Pajak secara simultan berpengaruh terhadap kepatuhan wajib pajak. Berdasarkan pada Omnimbus Tests yang dilakukan menunjukkan bahwa nilai signifikansi < 0,05 sehingga menolak H0, yang menunjukkan bahwa penambahan variabel independen dapat memberikan pengaruh nyata terhadap model, atau dengan kata lain model dinyatakan FIT.

Model regresi yang baik adalah dengan tidak adanya gejala korelasi yang kuat diantara variabel bebasnya. Hasil pengujian menunjukkan tidak ada nilai koefisien korelasi antar variabel bebasnya, hasil pengujiannya menunjukkan tidak adanya gejala multikolinearitas yang serius antar variabel bebas tersebut

\begin{tabular}{llcccccc}
\hline & & B & S.E. & Wald & Df & Sig. & Exp(B) \\
\hline Step & totx1 &, 299 &, 176 & 4,898 & 1 &, 029 & 1,349 \\
1(a) & &, 282 &, 124 & 5,139 & 1 &, 023 & 1,326 \\
& totx2 &, 291 &, 132 & 4,844 & 1 &, 028 &, 748 \\
& totx3 & $-2,987$ & 8,840 & 1 &, 003 &, 000 \\
\hline
\end{tabular}

Tabel 6.

Pengujian Hipotesis

Berdasarkan tabel 6. Pengujian hipotesis di atas, semua variabel independen mempunyai nilai signifikasi $<0,05$, artinya masing-masing variabel berpengaruh signifikan terhadap Y di dalam model. Sunset Policy mempunyai nilai Sig Wald $0,029<0,05$ sehingga menolak H0 atau yang berarti Sunset Policy berpengaruh signifikan terhadap kepatuhan wajib pajak orang pribadi. Dengan kata lain hipotesis 1 diterima. Tax Amnesty mempunyai nilai Sig Wald 0,023<0,05 sehingga menolak $\mathrm{H} 0$ atau yang berarti Tax Amnesty berpengaruh signifikan terhadap kepatuhan wajib pajak orang pribadi. Dengan kata lain hipotesis 2 diterima. Dan Sanksi Pajak mempunyai nilai Sig Wald 0,028<0,05 sehingga menolak H0 atau yang berarti Sanksi pajak berpengaruh signifikan terhadap kepatuhan wajib pajak orang pribadi. Dengan kata lain hipotesis 3 diterima.

Pada masing-masing hipotesis 1, 2, dan 3 dinyatakan bahwa sunset policy, tax amnesty, maupun sanksi pajak berpengaruh terhadap kepatuhan wajib pajak. Dengan kata lain pernyataan tersebut sesuai dengan hasil uji hipotesis 1, 2, dan 3 yang menyatakan bahwa sunset policy, tax amnesty, maupun sanksi pajak berpengaruh terhadap kepatuhan wajib pajak. Selain dilihat dari nilai signifikasi ketiga variabel yang $<0,05$, hal tersebut dapat dibuktikan dengan melihat tabel 5. Descriptive Statistic yang menunjukkan hasil perhitungan rata-rata dari sunset policy, tax amnesty, dan sanksi pajak mendekati nilai rata-rata kepatuhan WP sehingga dapat disimpulkan bahwa WP yang mengikuti program sunset policy, tax amnesty, maupun WP yang memahami tentang sanksi pajak cenderung patuh terhadap kewajiban perpajakannya yang artinya bahwa sunset policy, tax amnesty, maupun sanksi pajak mempengaruhi kepatuhan WP, dimana hasilnya menunjukkan sebagian besar WP telah mengikuti program sunset policy dan tax amnesty serta memahami sanksi pajak secara langsung dan telah merasakan manfaat atau keuntungan yang diperoleh. 


\section{Pengaruh Pelaksanaan Kebijakan...}

Berdasarkan teori atribusi, sunset policy, tax amnesty dan sanksi pajak merupakan penyebab eksternal yang mempengaruhi persepsi wajib pajak untuk berperilaku patuh dalam melaksanakan kewajiban perpajakan. Berdasarkan teori pembelajaran sosial, wajib pajak dapat belajar melalui pengamatan dan pengalaman langsung mengenai dampak diberlakukannya program sunset policy dan tax amnesty, untuk mengetahui apa fungsi serta keuntungan bila mengikuti program tersebut, yaitu wajib pajak tidak dikenakan sanksi administrasi perpajakan berupa bunga apabila secara sukarela melakukan pembetulan atas pajak pada tahun-tahun yang lalu serta penghapusan pajak yang seharusnya terutang tidak dikenakan sanksi administrasi dan sanksi pidana di bidang perpajakan dengan cara mengungkapkan harta dan membayar uang tebusan sebagaimana yang diatur dalam undang-udang. Keberadaan sunset policy dan tax amnesty merupakan kesempatan terbatas yang diberikan Pemerintah kepada organisasi atau individu untuk meningkatkan ketaatan terhadap peraturan pajak. Selain itu wajib pajak dapat belajar melalui pengamatan dan pengalaman langsungnya melalui pemberian sanksi yang dikenakan aparat pajak kepada wajib pajak yang melanggar norma perpajakan. Sanksi pajak dibuat adalah untuk mendukung agar wajib pajak mematuhi peraturan perpajakan. Kepatuhan wajib pajak akan ditentukan berdasarkan persepsi wajib pajak tentang seberapa kuat sanksi pajak mampu mendukung perilaku wajib pajak untuk taat pajak.

Hasil penelitian ini serupa dengan hasil penelitian yang dilakukan oleh Rantung (2009) dan Diaztika (2010) yang menemukan bahwa program Sunset Policy berpengaruh signifikan terhadap faktor-faktor yang mempengaruhi Kemauan Membayar Pajak serta Program Sunset Policy berpengaruh signifikan terhadap peningkatan penerimaan pajak dan meningkatkan kepatuhan wajib pajak dalam menyampaikan/membetulkan SPT. Selain itu penelitian ini mendukung hasil penelitian yang dilakukan oleh Gunawan dan Sukartha (2016) menemukan hasil bahwa tax amnesty berpengaruh positif terhadap penerimaan pajak di KPP Badung Utara. Kebijakan tax amnesty ini direspon secara positif oleh wajib pajak, yaitu dengan semakin meningkatnya kemauan membayar pajak. Dan hasil penelitian ini juga serupa dengan hasil penelitian yang dilakukan oleh Hadi (2010) menemukan bahwa tingkat pemahaman, pendidikan, dan penghasilan wajib pajak, serta sanksi perpajakan berpengaruh signifikan positif terhadap kepatuhan wajib pajak orang pribadi. Sanksi pajak dari deskripsi hasil penelitian menunjukkan bahwa wajib pajak orang pribadi di kota Bukittinggi cukup setuju diberikan sanksi pajak jika tidak memenuhi kewajiban perpajakannya.

Pada penelitian ini menunjukkan bahwa wajib pajak secara langsung mengikuti program sunset policy sehingga wajib pajak merasakan dampak positif dari program tersebut. Dan pada penelitian ini menunjukkan bahwa tingkat antusiasme WP dalam mengikuti dan mengamati program tax amnesty secara langsung sangat tinggi, yaitu ditandai dengan semakin meningkatnya kemauan WP dalam membayar pajak setelah diberlakukannya program tersebut. Wajib pajak telah mengetahui bentuk sanksi yang diberikan apabila melanggar aturan perpajakan sehingga presepsi wajib pajak terhadap sanksi perpajakan cenderung menakutkan dan merugikan. Hal tersebut membuat WP termotivasi untuk mematuhi peraturan yang ada atau dengan kata lain tidak melanggar norma.

Dari hasil penelitian diatas dapat disimpulkan bahwa sunset policy, tax amnesty dan sanksi pajak berpengaruh signifikan terhadap kepatuhan wajib pajak orang pribadi yang melakukan kegiatan usaha dan pekerjaan bebas di KPP Pratama kabupaten Dompu, dimana variabel yang sangat memiliki pengaruh adalah tax amnesty yang ditandai dengan tingginya nilai rata-rata pada tabel statistik deskriptif yang artinya bahwa mayoritas responden cenderung menjawab sangat setuju terhadap pertanyaan yang berkaitan dengan manfaat serta dampak pemberlakuan tax amnesty yang dapat meningkatkan kepatuhan wajib pajak orang pribadi di KPP pratam kabupaten Dompu. 
Penelitian ini bertujuan untuk mengetahui pengaruh pelaksanaan kebijakan Sunset Policy, Tax Amnesty, dan Sanksi Pajak terhadap Kepatuhan Wajib Pajak Orang Pribadi yang melakukan kegiatan usaha dan pekerjaan bebas. Penelitian ini dilakukan di lingkungan KPP Pratama Kabupaten Dompu dengan menggunakan sampel sebanyak 58 responden wajib pajak.

Penelitian ini memberikan kesimpulan bahwa pengujian empiris yang dilakukan menunjukkan hasil bahwa variabel sunset policy, tax amnesty, dan sanksi pajak berpengaruh positif signifikan terhadap terhadap kepatuhan wajib pajak.

\section{REKOMENDASI}

Berdasarkan hasil penelitian ini diharapkan untuk pemerintah khususnya Direktorat Jenderal Pajak (DJP) bisa membuka program yang sama dengan sunset policy dan tax amnesty untuk periode yang akan datang. Untuk memberikan evaluasi kepada wajib pajak yang selama ini tidak patuh dalam melaksanakan kewajiban perpajakannya, hal ini terbukti masih banyak wajib pajak yang mengikuti program sunset policy dan tax amnesty yang diterapkan pemerintah.

Serta diharapkan untuk peneliti selanjutnya bisa memakai hasil penelitian ini sebagai acuan untuk mengembangkan penelitian dengan mempertimbangkan variabel-variabel lain diluar variabel yang sudah masuk dalam penelitian ini. Selain itu peneliti selanjutnya diharapkan menambah dimensi pernyataan dalam setiap variabel yang ada di dalam kuesioner penelitian.

\section{DAFTAR PUSTAKA}

Alm, J., Jorge, M.,Vazquez \& Sally, W. 2009. Economic Analysis \& Policy. Do Tax Amnesty Work? The Revenue Effect of Tax Amnesties During the Transition In the Russian Federation, 32, 15-20.

Arum, Harjanti Puspa. 2012. Pengaruh Kesadaran Wajib Pajak, Pelayanan Fiskus, dan Sanksi Pajak Terhadap Kepatuhan Wajib Pajak Orang Pribadi Yang Melakukan Kegiatan Usaha dan Pekerjaan Bebas (Studi di Wilayah KPP Pratama Cilacap). Skripsi Tidak Dipublikasikan, Fakultas Ekonomikadan Bisnis, Universitas Diponegoro.

Darussalam, Danny 2011. Peningkatan Kepatuhan Wajib Pajak Melalui Komite Pengawas Perpajakan. Diakses pada 11 April, 2017 dari: www.ortax.org.

Gunawan, A., dan Sukartha, I. 2016. Pengaruh Presepsi Tax Amnesty Pertumbuhan Ekonomi dan Transformasi Kelembagaan Direktorat Jenderal Pajak pada Penerimaan Pajak. E-Journal Akuntansi Universitas Udayana, Vol.17.3.

Mutia, Sri Putri Tita. 2014. Pengaruh Sanksi Perpajakan, Pelayanan Fiskus, Dan Tingkat Pemahaman Terhadap Kepatuhan Wajib Pajak Orang Pribadi (Studi Empiris pada Wajib Pajak Orang Pribadi yang terdaftar di KPP Pratama Padang). Skripsi.Fakultas Ekonomi Universitas Negeri Padang.

Ngadiman, dan Huslin, D. 2015. Pengaruh Sunset Policy, Tax Amnesty, Dan Sanksi Pajak Terhadap Kepatuhan Wajib Pajak (Studi Empiris Di Kantor Pelayanan Pajak Pratama Jakarta Kembangan). Journal Tarumanegara, Volume XIX, No. 02, Mei 2015: 225-241.

Rahayu, Siti Kurnia. 2009. Perpajakan Teori dan Teknis Perhitungan. Yogyakarta: Graha Ilmu. Yogyakarta: Andi. 
Pengaruh

Pelaksanaan

Kebijakan...

1090
Rahman, Abdul. 2010. Panduan Pelaksanaan Adminitrasi Pajak Untuk Karyawan, Pelaku Bisnis Dan Perusahaan. Bandung: Nuansa.

Syaputri, Risaria. 2009. Penerapan Ketentuan Pasal 37A Undang-undang No.28 Tahun 2007 tentang Sunset Policy dalam Rangka Peningkatan Jumlah Wajib Pajak Orang Pribadi (Studi di KPP Pratama Jakarta Pademangan). Tesis Universitas Indonesia.

Wahyudi, Dimas Eko. 2017. Pengaruh Sunset Policy, Tax Amnesty dan Sanksi Pajak terhadap Kepatuhan Wajib Pajak. Skripsi Sarjana Universitas Muhammadiyah Malang.

Widodo, W., dan Dedi Djefris. 2008. Tax payer's right. Alfabeta: Bandung.

Zain, Mohammad. 2007. Manajemen Perpajakan.Jakarta: Salemba Empat. 